Article

\title{
Public Food Procurement as a Driving Force for Building Local and Agroecological Food Systems: Farmers' Skepticism in Vega Baja del Jarama, Madrid (Spain)
}

\author{
Marian Simón-Rojo ${ }^{1, * \mathbb{D}}$, Andrés Couceiro ${ }^{2}$, Julia del Valle ${ }^{3}$ and José Fariña Tojo ${ }^{4}$ \\ GIAU+S Universidad Politécnica de Madrid, 28040 Madrid, Spain \\ 2 Madrid Agroecológico, Surcos Urbanos, 28027 Madrid, Spain; andres@surcosurbanos.es \\ 3 Germinando Iniciativas Socioambientales S. Coop, 28012 Madrid, Spain; juliadelvalle@germinando.es \\ 4 Universidad Politécnica de Madrid, 28040 Madrid, Spain; jose.farina@upm.es \\ * Correspondence: m.simon@upm.es
}

Received: 29 July 2020; Accepted: 3 September 2020; Published: 8 September 2020

check for updates

\begin{abstract}
In the last decade, efforts to re-localize the food system have been gaining ground in a way that is intended to induce changes in the primary sector, thereby improving its conditions and sustainability. The European Union has identified food as one of the ten key sectors with outstanding potential for an ecological transition, and public procurement of (organic) food as an appropriate policy to foster agricultural development and support small farmers. In this study, we analyze changes in land use and farming dynamics in three municipalities close to the metropolitan area of Madrid (Spain). We also explore how stakeholders and farmers perceive the driving forces of these changes and the potential for public procurement in providing stability for farmers and more specifically, boosting the articulation and consolidation of the emerging agroecological sector in an up-to-date hostile peri-urban environment. Some urban policies and food strategies in nearby cities, such as Madrid, have introduced measures to promote sustainable food in public procurement. The procurement could drive $10 \%$ of the total food grown in the Comunidad de Madrid, with large variations in the impact on different food subsectors. However, if public procurement is to be organic, local production has no capacity to meet increases in demand, except for honey and oil. Food procurement would not lead to improved stability and increases in farmers' incomes if public policies to boost ecological transition are not adopted in parallel. For farmers, economic viability takes precedence over other problems, and although public procurement has been mainstreamed as a valuable tool to support local agriculture, stakeholders do not have high expectations for it. The research shows that farm size and specialization have a strong influence on market orientation, and the agroecological farmers and social movements that support them are primed for innovation adoption and may act as catalysts for the process.
\end{abstract}

Keywords: agroecology; Comarca de las Vegas; ecological transition; farming system; local food system; public procurement

\section{Introduction}

Globalization, which transforms food systems and the relationships among cities, urban areas, and the countryside, is now at a crossroads [1]. Current urban food systems are vulnerable and unable to meet the nutritional needs of the most vulnerable populations in cities [2]. The COVID-19 pandemic has highlighted these vulnerabilities, disrupting urban food systems worldwide [3]. 
The planet is facing an imminent socio-ecological crisis [4], and food is one of the most critical sectors where profound changes are needed. The group of high-level experts at the United Nations Committee on World Food Security explain that sustainable food systems respect the environment, protect biodiversity and ecosystems, and satisfy nutritional needs by providing culturally acceptable, accessible, and healthy food, while protecting and improving rural means of life, quality, and social wellbeing. In recent years, industrial agriculture, as well as intensive breeding, have been increasingly contested, and we are currently witnessing the spread of new consumption habits that will have an influence on farming. Agroecology is part of the eco-schemes present in the Common Agricultural policy (CAP) Reform and the "From Farm to Fork Strategy", to achieve these sustainable food systems [5]. As Altieri [6] explained, agroecology provides the knowledge and methodology necessary for developing agriculture that is environmentally sound, highly productive, socially equitable and economically viable. The Agroecology Knowledge Hub of the Food and Agriculture Organization (FAO) of the United Nations calls for agroecology to design resilient food systems and restore ecosystem services and biodiversity to fully deploy sustainable agriculture. Agroecology aims to replace industrial agriculture, which conflicts with natural processes, by applying ecological principles and concepts to the design and management of agroecosystems $[7,8]$, and allowing farmers to gradually eliminate inputs by relying instead on their interactions with natural antagonists [9].

The transition to sustainable food systems goes beyond agriculture, and strong actions are needed across the entire food chain. The connection between locality and sustainability has long been promoted by food sovereignty advocates [10]. Efforts to re-localize, at least partially, the food system are gaining ground in a way that is meant to induce changes in the primary sector, thereby improving its conditions and sustainability. It is also well documented that both crisis and proximity to a city can boost adaptation of some agricultural practices based on the growing urban demand for healthy and local food [11-13] in what has been called Urban Farming [14].

Indeed, the retail sector has incorporated "local" as part of their commercial strategies and there is an increasing presence of local food in supermarkets. The business model in restaurants and catering is now being "reinvented" and adapted to consumers' growing interest in local products, sensorial experiences around food, and values assigned to the sense of belonging and identity [15]. This relocalization reduces transport, but the rest of the conditions from the global system remain unchanged (e.g., large retail operators, intensive production even eco-intensive, unbalanced relationships, etc.).

The local governance context is also evolving at a high speed. An ally appeared recently, which aimed to transform urban food systems at a city scale. The Milan Urban Food Policy Pact (MUFPP) was launched in October 2015 and has since become a frame of reference, as a voluntary treaty signed by cities committed to working on the development of sustainable, inclusive, resilient, secure, and diversified food systems, to guarantee healthy food that is accessible for everyone. MUFPP proposes a rights-based model, aiming at reducing food waste and preserving biodiversity while mitigating and adapting to the effects of climate change. In many ways, this matches the Sustainable Development Goals (SDGs) outlined at the United Nations summit in September 2015. Food councils and food strategies are relatively new tools for designing local policies and have the potential to amplify and consolidate national and international efforts in this direction and to facilitate a more synergistic approach to implementing SDGs [16].

The European Union has identified food as one of the ten key sectors with outstanding potential for an ecological transition. It is considered a strategic economic sector due to the needs it meets, its high social and environmental impacts, and its transversality and ability to generate synergy with various economic sectors $[17,18]$. Green Public Procurement schemes provide a unique opportunity to integrate organic food and "to foster agricultural development by directing government food demand to domestic suppliers, particularly smallholder farmers" [3]. Within food procurement, school canteens deserve special attention to highlight their potential impact on the health and well-being of the population [19]. 
Altogether, farming systems are experiencing opposing trends. While major forces keep boosting global food systems, local food is gaining prominence with different approaches. Exploring a local reality allows us to confront how the tension between these two tendencies can be resolved, if ever. The global scale has already been analyzed using global statistics and reports. Nevertheless, understanding the context and specificities at the local level necessarily involves ad hoc fieldwork, as such data are not disaggregated, and qualitative information from stakeholders and local actors is not available. Therefore, we selected a case study in the region of Madrid (Spain), to explore some critical questions: what is being deployed in the area to induce a local reaction, who are the relevant social and political actors, and what is the desirable future they envision?

We explore the evolution of land uses and farming in the region to assess if the trends of abandonment and intensification observed in the Mediterranean basin [20] coincide with what is occurring in Madrid and what is being done to induce a local reaction. This research characterizes whether people at the local level consider taking advantage of proximity to a demand hotspot of over 4.5 million people, what public policies are implemented by different governments, and farmers' adoption of new business models and strategies linked to quality schemes and direct selling via short supply chains. We also analyze farmers' perceptions and demands, as well as those from civil society. In doing so, we echo the well-known triangle of public-private-civil society defined by Wiskerke [21]. We aim to determine if farmers have expectations towards public procurement and the re-location of the food system. These expectations are then weighed against estimated data on production and the impact that the public procurement of food may have on farmers' economies and more specifically, on the articulation and consolidation of the emerging agroecological sector in an up-to-date, hostile, peri-urban environment.

\section{Materials and Methods}

The research unfolds at two different scales: regional and local, and addresses three main issues:

- changes in land use and farming systems, with special attention to the emergence of new trends, such as agroecology and alternative food networks;

- stakeholder perception of the driving forces for these changes, the importance they assign to global and local drivers and what reaction takes place;

- public procurement's potential to support local agriculture and if it is part of farmers' plans.

This research builds on previous studies on the drivers of farm system changes, which have long been analyzed $[20,22,23]$. This one offers a complementary approach that innovates by relating stakeholder perception with objective data on changes. By doing that, we aim to better understand local attitudes and anticipate how public policies on public procurement could be better designed in cooperation with stakeholders to have a stronger impact on the transition towards a sustainable food system by improving farmers' conditions.

\subsection{Study Area}

The region of Madrid (Comunidad de Madrid) has 6.5 million inhabitants and aspires to consolidate itself as a large service hub. Since the 1980s, the capital city, Madrid, has sought to be included in the ranks of "global cities" and plans have been strategically oriented to build large transport infrastructure and promote urban megaprojects to make the city attractive to investors, companies, tourists, and citizens. Distinguished authors, such as Saskia Sassen, position Madrid in the top ranks of global cities, at least as a recipient of national and foreign investment in real estate [24].

Farming in the Comunidad de Madrid is distributed almost equally between agricultural crops and livestock. Farming, however, has become irrelevant $(0.10 \%)$ in terms of its contribution to the gross domestic product per capita (GDP) and the workforce (0.75\%). Paradoxically, the metropolitan area is a hotspot of food consumption. The regional food industry is oriented to satisfy food demand from the urban population, but the raw materials are not local $[25,26]$ and there is a very low proportion of 
self-supply of agricultural products. The figures on the origin of the food entering the region say a great deal. By 2003, food imports accounted for $€ 2330.60$ million euros, and by 2010, imports accounted for $98 \%$ of the total, a proportion that highlights the regional dependency of the food system, both in external ${ }^{1}$ supply areas and in the global chains. At the country level, Spain had a positive economic balance of exports-imports for its food, totaling €11,985 million euros in 2018.

On the one hand, the demand for local products is increasing; on the other hand, in some large cities, food policies are being implemented. In the case of Madrid (capital city), these measures are part of a food strategy [27] that goes beyond promoting healthy diets and sustainable consumption patterns and is also aimed at boosting local and agroecological production. In 2019, Spain adopted the Urban Agenda 2030 [28], whose first strategic objective is "Land use planning to make a more rational use of the land, conserve and protect it". It also seeks to reduce the risks of climate change, thus improving its resilience and fostering the circular economy and proximity in its production-consumption relationships. The objectives of the Urban Agenda cannot be achieved without addressing the issue of food.

Besides analysis at a regional scale, another study with a local focus was conducted. We selected three municipalities southeast of the Comunidad de Madrid (Figure 1), located in Comarca de Las Vegas, one of the most fertile plains of the region. In the past, cattle ranching also had an important presence. The rest of the area is occupied by rainfed crops and to a lesser extent, by olive groves.
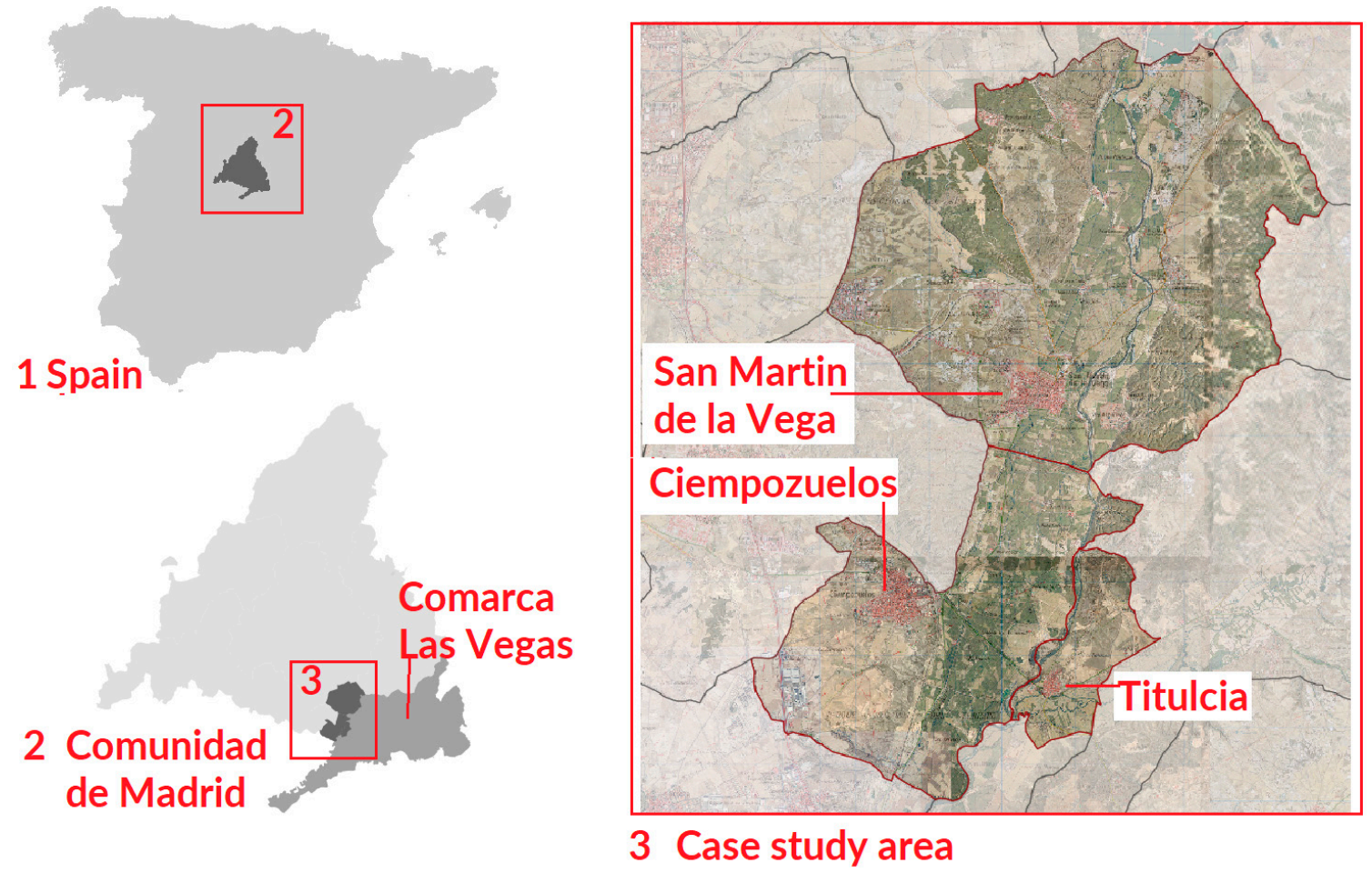

Figure 1. Case Study in Comarca de Las Vegas, Madrid, and Spain. Source: Author.

The area of study, extending over $165.47 \mathrm{~km}^{2}$, is crossed by the historical irrigation system Real Acequia del Jarama, dating from the $18^{\text {th }}$ century. Until the 1960s, the Comarca Las Vegas was an important source of food for the capital city. Nevertheless, its importance has diminished considerably, as vegetables in the area were mostly replaced by winter corn and cereals for feeding cattle. An intense agricultural activity is still maintained, albeit with decreasing importance, and agrarian uses compete with mining activities and extraction sites, as well as urbanization and other artificial uses. Since 1994,

1 External supply includes inputs from other Spanish's regions (Comunidades Autónomas). 
almost half the area has been protected within the Southeast Regional Park (Parque Regional del Sureste) and the three municipalities have a spatial master plan: a General Plan in Ciempozuelos (2006) and Subsidiary Norms in San Martín de la Vega (1997) and Titulcia (2000). In the Comarca de Las Vegas, there is an Operational Group led by the Agricultural Research Institute (IMIDRA), working on the definition of an agrarian park for this rural district (Comarca), one of whose nodes will be located in these three municipalities.

According to the Committee of Organic Agriculture in Madrid (CAEM) census, in these municipalities, the presence of organic production is limited to eight farmers, including an organic livestock farm with native breeds, and an oil company. The two agroecological projects in the area ('Huerta la Madre Vieja' in Ciempozuelos and 'Conciencia Grows' in San Martín de la Vega), together with other agroecological projects, have recently launched an association of agroecological orchards.

Usually, only organic and agroecological farmers experience a positive trend, although the experiences of the latter usually remain invisible to official statistics. In recent years, diverse quality schemes and labels have been deployed with the aim of promoting local products. In the Comunidad de Madrid, the "M de Madrid" brand identifies quality products grown or processed in the region. The Designation of Origin Oil of Madrid is a scheme regulated by the European Union (EU), which protects extra virgin olive oil obtained by mechanical procedures. The oil produced in the three municipalities is protected by this Designation of Origin. Titulcia's wines are covered by the Designation of Origin Wines of Madrid, sub-region of Arganda. At the local level, Ciempozuelos launched a local quality label denoting "Vega de Ciempozuelos", with the aim of "promoting the consumption, identification, and marketing of products from the garden" in the municipality. This was intended to provide technical assistance to local horticulturists to support their marketing, but the activity stopped and has had a low impact.

Most of the agricultural production in the area is commercialized through Mercamadrid ${ }^{2}$, the main platform for the distribution, commercialization, transformation, and logistics of fresh food in the Spanish State. The regional government is planning a new Mercarural, close to the area of the case study, as a logistic hub for regional agrarian production.

\subsection{Agricultural Land Use and Production and Consumption of Local Food}

We analyze land use and food production at a regional level in the Comunidad de Madrid. CORINE Land Cover provides the basic information about changes in agrarian land uses between 2000 and 2018. More detailed spatial information on cultures come from the Map of Cultures and Yields and the Agricultural Plots Information System of Spain (SIGPAC in Spanish). Statistical data on production were provided by Eurostat and the Ministry of Agriculture through the Spanish Agricultural Census 2009 and annual reports on Surfaces and Yields. Contrary to the available spatial information, statistical data about yields are not disaggregated at the municipal level.

Detailed information at the municipal level on organic farming production is not available, so we rely on yield statistics at the regional level, published on an annual basis by the Ministry of Agriculture (2019). The register of organic enterprises is also not fully reliable for that purpose, as it provides the owner's address but not the location of the farms; however, it does give an idea of the number of organic farmers in the area of the case study (i.e., eight).

The research pays special attention to agroecological projects for their innovative character. We updated the data provided by the platform Madrid Agroecologico on agroecological projects in the region, resulting in a database with 125 entries: 71 agricultural projects, 21 cattle breeders, and 33 food processors. Then, a survey was conducted by telephone together with the cooperative Germinando to characterize the agroecological sector in terms of its size, production, economic orientation, and performance. All projects were called and 64 agricultural farmers, 17 cattle breeders, 
and 7 food processors answered the questionnaire, achieving a $\mathrm{n} / \mathrm{N}$ ratios of 90,91 , and $33 \%$. There is no official census of agroecological projects, so we assumed that some of these farmers do not surface. Even so, the results provide a consistent report of the sector that can be compared with the conventional one. As this research explores the questions on farmers' marketing channels, we had special interest in recognizing the short-supply chains operating in this agroecological sector. The farmers were asked about the percentage of their sales to processors, conventional distribution channels, and direct selling. For the latter, they were also asked if sales were done on-farm, through a website, at farmers' markets, through consumer groups or small shops, via social distribution companies, at restaurants or school cafeterias, through catering, or by other means.

Mapping the whole local food system at the regional (NUT3) level was unfeasible within this study, so we began this analysis at the local level for two outstanding agricultural products (oil and asparagus) and obtained a basic map of the local food chain for these products. Within the research, we considered local consumption limited to the three municipalities considered, and the closest main cities (Madrid and the metropolitan area). The information was obtained through interviews with one of the two organic olive companies in these municipalities, the person responsible for the "Oil of Madrid" designation of origin, one of the three asparagus producers in Ciempozuelos, and another horticultural agroecological farmer.

\subsection{Farmers and Stakeholder Perceptions}

The first stage of the research provided the quantitative base for analysis. This second stage was essential to outline the qualitative aspects, exploring how local stakeholders perceive the constraint factors and the drivers of changes in land use, farming, and local food systems. Survey research was conducted with key informants based on open-ended questions on public policies (urban and territorial plans, food strategies, public procurement, markets, labels, access to land and equipment, training, financial support, and sensitization programs), new technologies (with special attention given to Information and Communication Technology (ICT), and socioeconomic factors. The interviewees explained how they perceive the main changes in land systems, management practices, and local food markets during the last ten years and their perspectives on the next thirty.

Selection criteria to identify key informants included: (a) representativity (favoring voices from groups or entities that comprise different partners, especially from the primary sector); (b) knowledge of the study area; (c) empirical or research-based experience in the relocation of food systems; and (d) a diversity of profiles, with people from a broad range of sectors. According to the Agrarian Census 2009, there were 552 farmers in these municipalities, and only eight of them were organic. This research did not pretend to interview all farmers as individual production units but instead sought to understand their perspective through their representatives (Association of Agro Cooperatives and the most active Agrarian Union in the area). For organic olive and asparagus, the sample was small (2 and 10, respectively), and we interviewed three farmers engaged in short supply chains. For researchers, we selected those working directly in the area or specialized in short-supply chains and relocalized agri-food systems from the Spanish National Research Council (CSIC) and the Rural, Food and Agriculture Development and Research Institute in Madrid (IMIDRA). The agroecological platform interview brought together more than 15 entities, some of them comprising networks with over 20 associations. We conducted 13 interviews between January and March 2019, including stakeholders from the primary sector (3), the administration (3), agricultural organizations (2), researchers (3), consultants (1), and social movements (1).

Interviews were complemented with workshops at the regional and local levels. In May 2018, a seminar took place to advance a diagnosis of the agrarian sector and local food systems in the Comunidad de Madrid (regional scale). There were three parallel sessions on training and innovation in the agrarian sector; preserving landscape and biodiversity; and promoting local consumption and short supply chains. Participants included technicians from the regional agriculture department, 
regional and national research agencies, agrarian unions and representatives from social movements, agroecology, and the social and solidarity economy sector.

The local scale was explored in January 2019. A Territory Game [29] in Ciempozuelos (Madrid) brought together 10 local stakeholders: technicians/researchers from public institutions (2), consultants (2), and those in the primary sector (practitioners, managers and agrarian union) (5), and social movements (1). The workshop was conducted to identify how the respondents perceived the evolution of their land systems, which improved scenarios they imagined and the actions needed to achieve those scenarios. Three questions guided the workshop: (1) are changes in the agrarian sector bringing you closer to or farther away from local markets? Do they have a positive or negative effect on biodiversity? (2) Considering a 2050 scenario: what economic alternatives could be developed at the local level to reinforce the local agrarian sector?

\subsection{Public Food Procurement}

The public procurement demand for local food was estimated at a regional scale, based on all institutional expenditures of food. We estimated the food procurement demands for each group of food, based on the global values (available for 2004) [30] and applying the corresponding ratios of the $\mathrm{kg}$ or liters consumed annually per capita to the population in 2018. Afterwards, we compared the results with what was cultivated in the region that year, both overall and certified as organic. The Ministry of Agriculture publishes annual statistics disaggregated by Autonomous Communities in two different reports, one of which considers only organic production [31].

A transition program incorporating ecological and proximity food criteria in public kindergarten canteens is already underway [27]. Data about registered minors provided by the Municipal Department of Education and the information available about the introduction of food groups with ecological criteria during the 2017-2018 and 2018-2019 academic years [32].

Criteria for the introduction of organic food are more common than those dealing with favoring regional food production, as the latter has faced accusations of "breaking open competition principles". Recent reports from the EU addressing this issue paved the way for including short supply chains as a criterion. Therefore, we start by analyzing scenarios related to the local supply of food and then combine local and organic production.

The analysis is focused on the Comunidad de Madrid. Although we know that the supply of "local" food exceeds the administrative limits of the region, in terms of governance and articulation of policies, it is important to inform public policies and decisions with data analysis of what falls under regional government competences.

\section{Results}

\subsection{Changes in Land Uses, Farming, and Food Marketing}

According to Eurostat ${ }^{3}$, in the Comunidad de Madrid, the agricultural area shrunk from 434,790 hectares in 2005 to 377,770 in 2013 , which represents a reduction of $13 \%$. In this period, the agricultural area being used and the number of farms decreased by $12 \%$. In monetary terms, this sector remains more stable, as the decrease was limited to $5 \%$. Conversely, the decline was stronger in terms of employment, with a reduction of $24 \%$ of the labor force in the sector.

This cessation of activity does not necessarily mean that agricultural land cover will disappear immediately (something evident in crops other than annual crops e.g., woody crops). Between 2000 and 2018, according to the CORINE Land Cover datasets, 57,000 hectares of agricultural land were transformed into other uses. As can be observed in Figure 2, up to $97 \%$ of these 57,000 hectares diverted from agricultural use ended up as artificial land (urban, industry, infrastructures, etc.). This impressive

3 http://appsso.eurostat.ec.europa.eu/nui/show.do?dataset=ef_oluaareg\&lang=en 
figure evolved during this period: artificial uses caused $98.5 \%$ of the total loss of agricultural land between 2000 and 2006, 94\% between 2006 and 2012, and 72\% between 2012 and 2018; the decrease in land consumption during this last period is associated with the slowdown in the construction sector forced by the economic downturn.

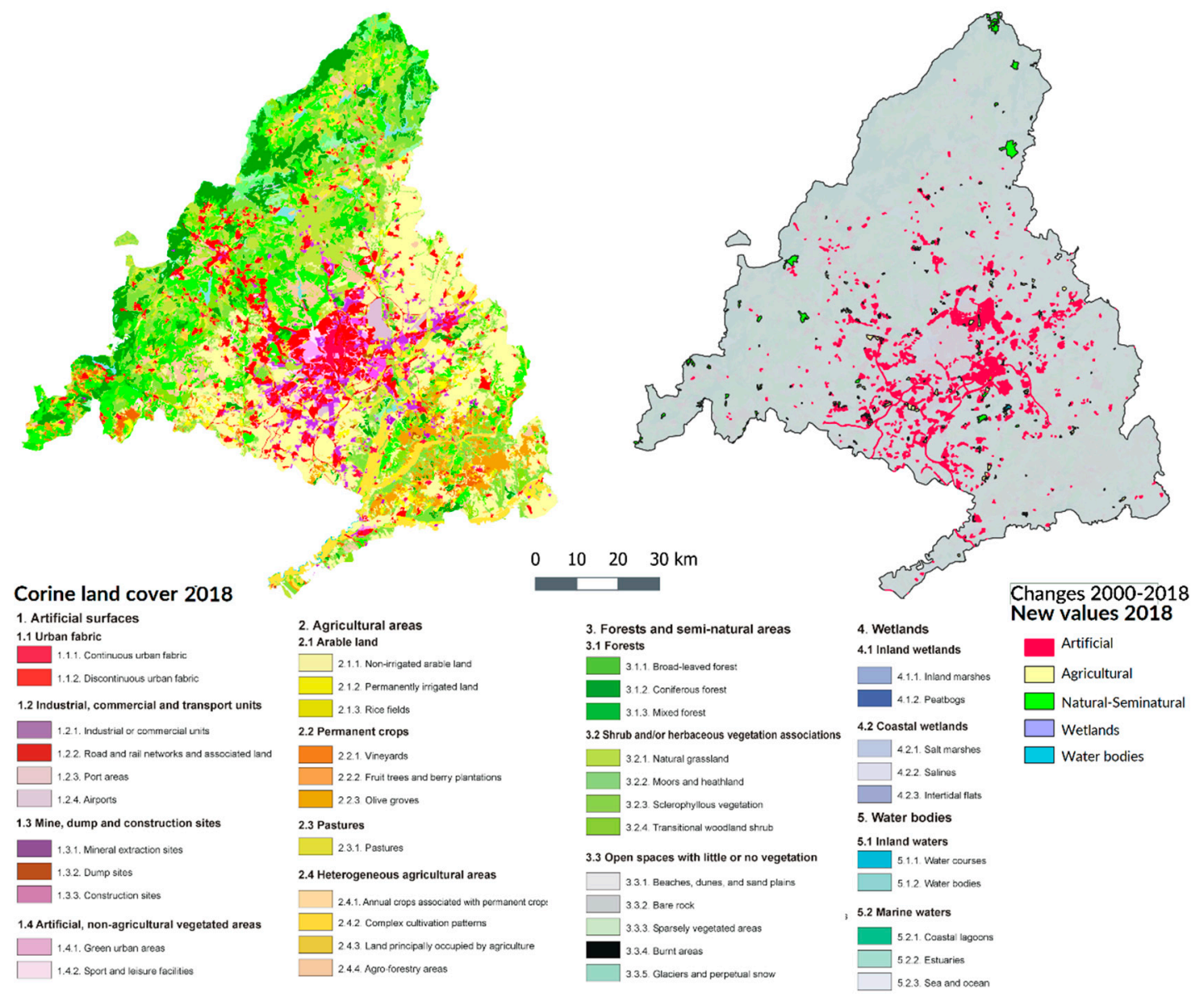

Figure 2. Land Use Changes Comunidad de Madrid 2000-2018. Source: The author based on CORINE Land Cover (CLC) databases.

The process of agriculture being weighed down was also reinforced by artificial uses and urban pressures in the three municipalities analyzed: urban and industrial soils in the surrounding areas of the towns (especially in Ciempozuelos), new tertiary uses such as the Warner Park in San Martín), and the opening of new gravel extraction sites along the fertile plain, especially north of San Martín). Overall, the agricultural area used has decreased considerably in San Martín de la Vega and Ciempozuelos and more land has gradually become possessed by fewer hands.

In the area beyond the limits of the Regional Park, an edge effect is observable (Figure 3). Often, this area is not considered valuable enough to be protected from urbanization and is assigned for urban development. Ciempozuelos' Master Plan designated 590 hectares for urban development, covering the entire land area between the limit of the Park and the western boundary of the municipal area (Figure 3). San Martín's Master Plan (Normas Subsidiarias) designated 542 hectares for urban development (40\% on agricultural land and $60 \%$ to complete the existing urban fabric). In Titulcia, the Master Plan designated 36 hectares for urban development. Farmers, social movements, and researchers have identified urban planning and urban expansion as factors that distort and hinder agriculture. At the riverside, the exploitation of gravel pits and plaster beds is also a serious problem for agricultural land, causing important and irreversible alterations in ecosystems and landscapes. Agricultural land within the Regional Park is not enough protected from disturbances caused by artificial uses such as 
extraction sites, facilities, and above all, holiday homes or other buildings. As can be observed in Figure 3, these artificial uses are more common in the land preserved from urbanization that is part of the Regional Park, than in the areas designated for development according to the Master Plans.

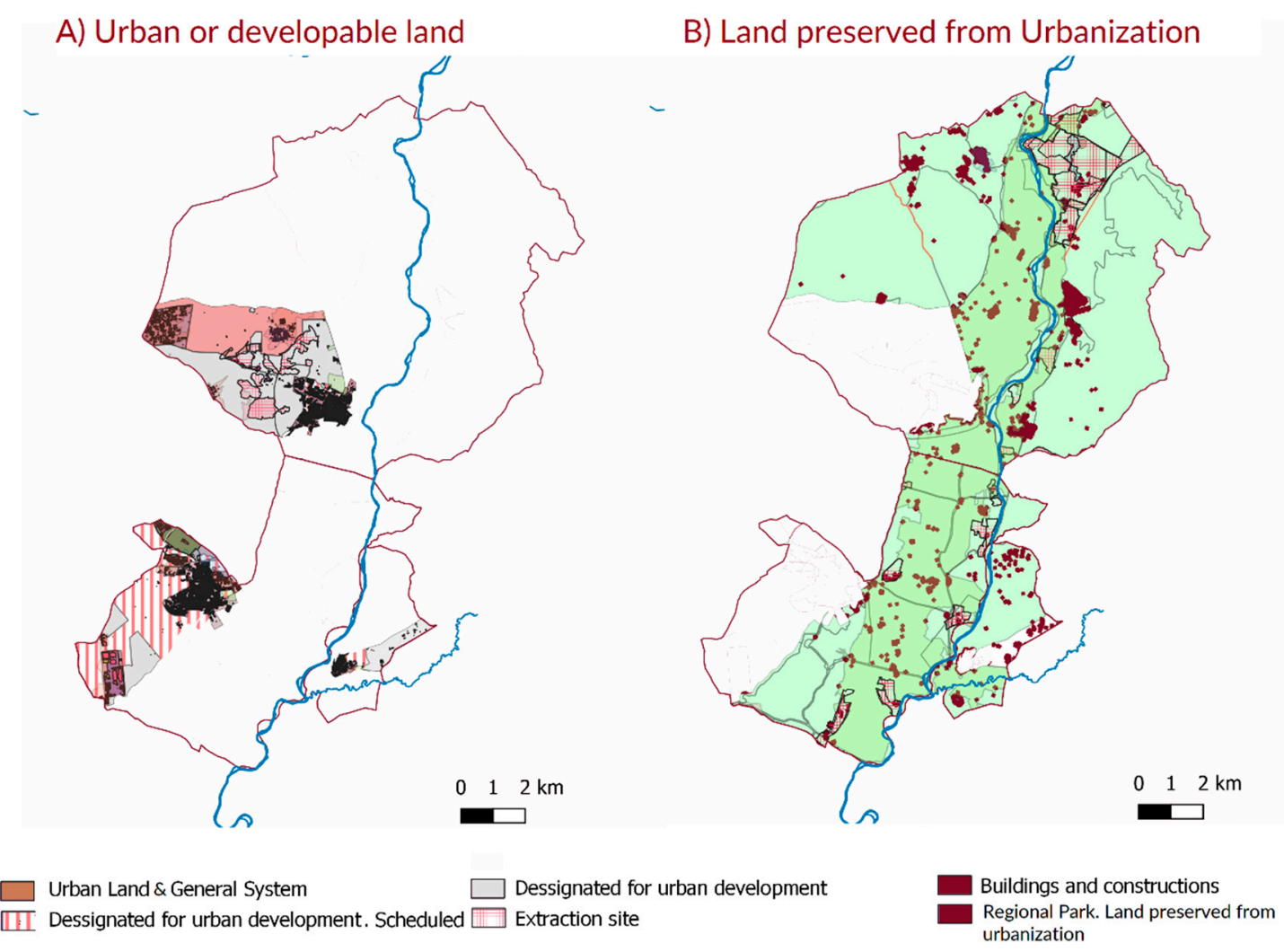

Figure 3. Buildings in the Protected Regional Park and in areas designated for urban development. Source: Author, based on the Sistema de Información Territorial of Madrid (Planea).

Research shows that farm size and specialization have a strong influence on the market orientation of farms. Decades ago, the area was very popular for asparagus cultivation; in Ciempozuelos, the agricultural cooperative of San Isidro Labrador marketed artichoke and to a lesser extent, other vegetables. This same cooperative, whose importance and influence in the territory has waned, now markets only corn. Pastures and livestock trails have also been lost due to the disappearance of extensive livestock farming, which was traditionally very important. Small farms prefer short supply chains, as they have no capacity to negotiate prices in large distribution schemes. Most agroecological projects have small dimensions, (an average of 2.2 Ha for horticultural-fruit production, and $33.7 \mathrm{Ha}$ for olive and wine), and all of them are engaged in direct selling. The orientation towards local markets and short supply chains is a common characteristic of agroecological farmers throughout the region of the Comunidad de Madrid. According to the survey at the regional level, all respondents (81 agroecological farmers) are engaged in short supply chains. Marketing through consumer groups stands out, as up to $60 \%$ of agroecological projects use this channel for sales. Moreover, $49 \%$ engage in on-farm direct sells, $39 \%$ attend farmers' markets or similar, $37 \%$ sell through small shops, and $28 \%$ sell to restaurants. Almost $19 \%$ engage in online sales, whereas only $2.5 \%$ sell to school canteens (vegetables and oil). Marketing through large distribution channels or conventional supermarkets is residual, involving only $1 \%$ of farmers (only livestock farmers). Under the COVID-19 lockdown, there was a considerable increase in home delivery. Moreover, farmers with Community Supported Agriculture (CSA) schemes increased their sales (especially vegetables) by providing home delivery to new customers. 
In the three municipalities, small-scale marketing survives, almost residually, through direct sales. None of these municipalities has a municipal market, but farmers still sell their vegetables at the front doors of their homes (also non-farmers). Short supply chains also include shops and restaurants in nearby towns.

On the other hand, some local companies have adopted more complex direct selling marketing strategies. That is the case for the Aceitera de la Abuela, (organic oil), which has diversified its packaging, size, and quality to meet different consumer preferences, thereby entering new market niches. The association promoting the Organic Oil Quality label is convinced that healthy food is entering the mainstream and that there is, in Madrid, a consumer segment ready to pay for high quality and expensive oil, which would absorb all the production in the region.

\subsection{Stakeholder Perception of Changes in the Agricultural Sector. Drivers, Constraints, and Potentials}

Interviewees and participants in the Territory Game pointed out that the above-mentioned changes have been induced or fundamentally favored by public policies, subsidies and (to a lesser extent) artificial use pressures. Table 1 summarizes how economic, institutional, and social stakeholders perceive the influence that different factors have had on facilitating short supply chains and the consumption of local food. By local, we mean areas within the municipalities and the metropolitan area.

Table 1. Factors that exert an influence on farming dynamics according to stakeholders.

\begin{tabular}{|c|c|c|c|c|c|c|}
\hline & \multicolumn{3}{|c|}{ Economic } & \multicolumn{2}{|c|}{ Institutional } & \multirow{2}{*}{$\begin{array}{c}\text { Social } \\
\begin{array}{c}\text { Agroecology } \\
\text { Movement }\end{array}\end{array}$} \\
\hline & Farmers & $\begin{array}{c}\text { Associations } \\
\text { (Unions, Coops) }\end{array}$ & Consultants & Political-Managers & Researchers & \\
\hline \multicolumn{7}{|c|}{ Public policies } \\
\hline $\begin{array}{l}\text { Common Agricultural } \\
\text { Policy and subsidies }\end{array}$ & -- & $-/+$ & - & - & $-1+$ & - \\
\hline Spatial planning & - & - & $Q$ & - & - & - \\
\hline Urban Food Strategies & $Q$ & $Q$ & + & $Q$ & - & + \\
\hline Public procurement & $Q$ & $Q$ & $+/-$ & + & ++ & ++ \\
\hline $\begin{array}{c}\text { Market } \\
\text { administration }\end{array}$ & + & + & - & + & + & - \\
\hline Labeling & - & + & $+/-$ & + & $+/-$ & $+/-$ \\
\hline $\begin{array}{c}\text { Access to } \\
\text { land/facilities }\end{array}$ & - & $Q$ & - & $Q$ & $Q$ & - \\
\hline Awareness programs & $Q$ & + & - & + & + & $Q$ \\
\hline \multicolumn{7}{|c|}{ Innovation } \\
\hline Production technics & $Q$ & ++ & $Q$ & $Q$ & ++ & $+/-$ \\
\hline $\begin{array}{l}\text { Information and } \\
\text { Communication } \\
\text { Technology (ICT) }\end{array}$ & + & $Q$ & $Q$ & $Q$ & + & $Q$ \\
\hline Social innovation & + & $Q$ & + & $Q$ & ++ & + \\
\hline \multicolumn{7}{|c|}{ Social context } \\
\hline Urban growth & - & $Q$ & $Q$ & $+/-$ & - & - \\
\hline $\begin{array}{c}\text { Health/environment } \\
\text { interest }\end{array}$ & + & ++ & + & + & + & ++ \\
\hline Economic Crisis & $Q$ & $Q$ & $Q$ & - & + & $+/-$ \\
\hline Aging Agrarian Sector & -- & $-/+$ & $Q$ & $Q$ & $-1+$ & $Q$ \\
\hline
\end{tabular}

A sentence from a representative of the agrarian cooperatives encapsulates how price and shrinking profitability have conditioned the evolution of farming: "You cannot make a living with the same surface of farmland as before". All stakeholders agreed that the factor with the strongest influence over farming evolution is the Common Agricultural policy (CAP) with its system of subsidies, against which 
they feel powerless. These influences have conditioned Spanish farming production, leading to the intensification of cereal cultivation-mainly corn and other winter crops. In the area, farmers explained that horticultural and livestock management are more time-demanding, but this extra work does not result in higher revenues. Therefore, farmers shift to cereals with better ratio effort-benefits and more stable prices. Respondents also stated that the area lacks a solid food processing industry. Many of the facilities that operated in previous times, like dryers, are no longer in use, and the added value of local production is low. Notably, both the agro cooperatives and researchers understood that CAP also has a positive influence on favoring organic production, especially for crops such as olive, which often use low intensity management practices.

Within public policies, spatial planning is an inhibitor of the local food system for all interviewees but the consultants. Nevertheless, none of the respondents payed much attention to this factor. Lack of policies on access to land and facilities is also a problem according to the farmers, consultants, and social movements.

On the other hand, public policies dealing with markets (mainly street markets) are positively perceived by all stakeholders, except for the consultants and social movements, whereas for labeling, the perceptions are more diverse. The local government that launched one local labeling supports these types of measures, as does the cooperative involved in quality schemes. Consultants and researchers acknowledge that some quality schemes have worked efficiently, such as for wine and organic oil, but they feel that, in global terms, labeling has already reached its limits, referring to "saturation" and "confusion among consumers".

The potential of public procurement is much appreciated by social movements and researchers, as well as by politicians and managers, but the agricultural sector does not perceive public procurement as a driver, and it remain absent from their narrative. Urban Food Strategies are narrowly related to public policies, but, once again, farmers are unfamiliar with them and feel that their potential positive effects do not reach them.

The aging of the sector, the lack of generational change, conformist attitudes, and individualism with low levels of agricultural cooperatives in this area have led to a vicious cycle and have deepened the problems of the primary sector [33]. The new generation of younger farmers, usually without a farming background, introduce innovations or adapt traditional management practices from prior to the industrialization of agriculture. Farmers and farmer association stress that the loss of cooperation among farmers results in lower competitiveness and profitability.

For innovation, ICT is not perceived as a relevant driver, only farmers and researches mentioned apps and social networks, and described their use of them "not as a groundbreaking, but as a facilitator. First, you need to build a relationship face-to-face, and then technology eases the economic transactions". Researchers and cooperatives/unions identified technology improvement as an important driver, specifically for olives (i.e., earlier collection and cold press, which resulted in improved quality).

There is consensus regarding social innovation as one of the main drivers boosting transitions into relocalized food systems. Alternative Food Networks, Community Supported Agriculture, and other channels that rely on building new and direct "solidarity" relationships between producers and consumers are mentioned as key elements of this relocalization. Some farmers, outside of the agroecological network or sphere are not as optimistic about this trend: "The amount of people that are ready to support high quality and local production is still very low and do not reach us".

In any case, the respondents noted that "now, consumers have the power" and highlighted that consumers are increasingly worried about health and, to a lesser extent, about environment degradation. This is perceived as the driver with the strongest positive influence on orienting local agriculture to local markets.

Therefore, when looking for opportunities, both the private and the public sectors recognize that proximity to a wide and diverse market such as the metropolitan region with more than 5 million inhabitants offers the greatest potential for the development of the primary sector. 
Producers were also in favor of hybrid marketing and diversified channels, without noting contradictions between the two options: Claiming support for local production, in connection with sustainability policies, is compatible with looking for export routes for their production, if the relevant stakeholders can obtain better prices. Only the agroecological movement and farmers seek to direct its production exclusively to local markets. They do not approach the problem with a lens of "niches" (e.g., organic and quality), but instead refer to the importance of reinforcing the links between production and consumption and discuss identity and revisit the culture surrounding localness and food.

In the municipalities considered, the potential role that proximity to large urban centers can play in the revitalization of the sector is interpreted in terms of multifunctionality and diversification, underpinning the traditions of horticultural and livestock. Therefore, the farmers proposed to revitalize this tradition by diversifying crops, reintroducing native livestock species, and recovering pastures and livestock trails. In this sense, the agrarian sector indicates that this evolution would be possible if farmers obtained support from the administration and local development organizations. They envision this process in connection with tourism and leisure, via schemes of stewardship within the management plans for the Regional Park. The respondents recognized the Regional Park as a consolidated figure of protection that considers the territory in which the agrarian activity is carried out, whereas urban plans are identified as development plans that are mainly concerned with urban issues (Figure 3). Local stakeholders and landscape managers state that, once the land is designated for urban development, investors enter the scene and agricultural activity stops. Sometimes, where rainfed land is concerned, local farmers occupy these "transitional" properties waiting for urbanization and cultivate them on their own.

In the Territory Game explained previously, the agents distributed in the two groups sought two desired scenarios for the future. To operationalize these projected scenarios, they proposed a series of actions dealing with the drivers of change and constraint factors.

The first group, which had a more general profile (as the majority did not work directly in the territory), concluded with the scenario "2050: Interlacing the living earth", based on the coordination and articulation between actors. The bidirectional knowledge transfer between research and practitioners was of utmost importance, including the figure of the "farmer master" as a reference for the rest. Moreover, important was the diversification of crops and activities, which included livestock, and the promotion of small food processing industries. All were accompanied by educational programs on eco-social values and support for short supply chains.

This first group proposed a participatory diagnosis and highlighted actions aimed at providing a public agricultural extension service through training in organic agriculture for farmers and environmental awareness programs for consumers (in co-operation with community gardens and consumer groups). These actions would be accompanied by the constitution of Governing Councils in cooperatives. Institutional action and awareness thus received significant attention.

The second group included a greater presence of agents linked to the local agrarian sector (directly or indirectly) and proposed the "2050 scenario. Back to the future". This scenario entails recovering some traditional agrarian dynamics but with innovations adapted to the $21^{\text {st }}$ century. The agents agreed on the need to diversify production, as well as recovering orchards and fruit trees, biodiversity and the landscape. In this scenario, the agents envisioned an increase in jobs related to farming in connection with an agricultural cooperative and the promotion of local trade and short supply chains. Likewise, the regulation of gravel pits and the environmental recovery of their spaces were noted, as well as improvement to the water quality in the Jarama river (even with bathing areas), and the promotion of ecotourism.

This second group identified the agrarian sector itself as the protagonist and leader of the transition process, after overcoming the individualism that characterizes the sector. A proposed fundamental action was the creation of a single agricultural cooperative. This was also considered key to increase the agrarian sector's awareness of the need to recover the horticultural tradition and receive training in this regard. Leadership by professionals and agrarian unions needs to be complemented by public 
policies that support local farmers' markets, and short supply chains. In addition, they ask for public investments, which are essential for modernization, innovation, and renovation of infrastructures, especially irrigation.

\subsection{Public Procurement}

Public food procurement's role in improving conditions for the agricultural sector has been echoed in the academic world as well as in technical spheres from the EU. Interviewees and participants in this study had a more nuanced attitude towards public procurement. We analyzed the repercussion that a shift in institutional food expenses toward local and ecological production could have.

According to official statistics [34], in the Comunidad de Madrid, the foods with the greatest weight in public procurement are: milk for drinking and dairy, meat, fruit, potatoes, and vegetables. In monetary terms, the highest expenditures, in descending order, are meat, fish, dairy products, and fresh fruits.

There is a significant variation in the standards regulating public food procurement in policies. Often, such policies set thresholds for organic food and may also include criteria to encourage short supply chains. These percentages vary, but for the purpose of our calculations, we selected three scenarios, in which 20,50 or $100 \%$ of the total institutional food consumption is supplied a) by local or b) by local organic farmers (Table 2 ).

Table 2. Comparison of food demand from institutions and supply capacity in the Comunidad de Madrid.

\begin{tabular}{|c|c|c|c|c|c|}
\hline \multirow{2}{*}{ Food } & \multirow{2}{*}{$\begin{array}{l}\text { Institutional Food } \\
\text { Procurement Demand } \\
\text { (Tons or Liters) }\end{array}$} & \multirow{2}{*}{$\begin{array}{l}\text { Production (Tons } \\
\text { or Liters) } \\
\text { T: Total O: Organic }\end{array}$} & \multicolumn{3}{|c|}{$\begin{array}{c}\text { Ratio Demand/Production } \\
\text { T: Total Production; O: Organic Production }\end{array}$} \\
\hline & & & $100 \%$ Demand & $50 \%$ Demand & 20\% Demand \\
\hline Milk, dairy & 28,382 & $\begin{array}{l}\text { T: } 82,000 \\
\text { O: } 3449\end{array}$ & $\begin{array}{l}\mathrm{T}: 35 \% \\
\mathrm{O}: 823 \%\end{array}$ & $\begin{array}{l}\mathrm{T}: 17 \% \\
\mathrm{O}: 411 \%\end{array}$ & $\begin{array}{c}\mathrm{T}: 7 \% \\
\mathrm{O}: 164 \%\end{array}$ \\
\hline Meat & 17,035 & $\begin{array}{l}\text { T: } 148,719 \\
\text { O: } 57\end{array}$ & $\begin{array}{c}\text { T: } 12 \% \\
\text { O: } 29,888 \%\end{array}$ & $\begin{array}{c}\text { T: } 6 \% \\
\text { O: } 14,944 \%\end{array}$ & $\begin{array}{c}\text { T: } 2 \% \\
\text { O: } 5977 \%\end{array}$ \\
\hline Fruit & 16,620 & $\begin{array}{l}\text { T: } 923 \\
\text { O: } 19\end{array}$ & $\begin{array}{c}\text { T: } 1800 \% \\
\text { O: } 85,763 \%\end{array}$ & $\begin{array}{c}\text { T: } 900 \% \\
\text { O: } 42,881 \%\end{array}$ & $\begin{array}{c}\text { T: } 360 \% \\
\text { O: } 17,152 \%\end{array}$ \\
\hline Potatoes & 14,639 & $\begin{array}{l}\text { T: } 10,460 \\
\text { O: } 17\end{array}$ & $\begin{array}{c}\mathrm{T}: 140 \% \\
\mathrm{O}: 85,863 \%\end{array}$ & $\begin{array}{c}\mathrm{T}: 70 \% \\
\mathrm{O}: 42,881 \%\end{array}$ & $\begin{array}{c}\text { T: } 28 \% \\
\text { O: } 17,152 \%\end{array}$ \\
\hline $\begin{array}{l}\text { Vegetables } \\
\text { (fresh or } \\
\text { processed) }\end{array}$ & 11,678 & $\begin{array}{l}\text { T: } 60,832 \\
\text { O: } 416\end{array}$ & $\begin{array}{c}\text { T: } 19 \% \\
\text { O: } 2805 \%\end{array}$ & $\begin{array}{c}\text { T: } 10 \% \\
\text { O: } 1402 \%\end{array}$ & $\begin{array}{c}\text { T: } 4 \% \\
\text { O: } 561 \%\end{array}$ \\
\hline Oil & 4448 & $\begin{array}{l}\text { T: } 32,123 \\
\text { O: } 5100\end{array}$ & $\begin{array}{c}\text { T: } 19 \% \\
\text { O: } 87.2 \%\end{array}$ & $\begin{array}{c}\text { T: } 7 \% \\
\text { O: } 43.6 \%\end{array}$ & $\begin{array}{c}\text { T: } 3 \% \\
\text { O: } 17.4 \%\end{array}$ \\
\hline $\begin{array}{c}\text { Cereals } \\
\text { derivatives }\end{array}$ & 9607 & $\begin{array}{c}\text { T: } 297,183 \\
\text { O: } 632\end{array}$ & $\begin{array}{c}\text { T: } 3 \% \\
\text { O: } 1519 \%\end{array}$ & $\begin{array}{c}\text { T: } 2 \% \\
\text { O: } 760 \%\end{array}$ & $\begin{array}{c}\text { T: } 1 \% \\
\text { O: } 304 \%\end{array}$ \\
\hline Pulse & 2255 & $\begin{array}{c}\text { T: } 9202 \\
\text { O: } 3\end{array}$ & $\begin{array}{c}\text { T: } 24 \% \\
\text { O: } 66,924 \%\end{array}$ & $\begin{array}{c}\text { T: } 12 \% \\
\text { O: } 33,462 \%\end{array}$ & $\begin{array}{c}\text { T: } 5 \% \\
\text { O: } 13,385 \%\end{array}$ \\
\hline Nuts & 114 & $\begin{array}{l}\text { T: } 555 \\
\text { O: } 15\end{array}$ & $\begin{array}{c}\text { T: } 20 \% \\
\text { O: } 745 \%\end{array}$ & $\begin{array}{c}\mathrm{T}: 10 \% \\
\mathrm{O}: 373 \%\end{array}$ & $\begin{array}{c}\text { T: } 4 \% \\
\text { O: } 149 \%\end{array}$ \\
\hline Honey & 16 & $\begin{array}{l}\text { T: } 218 \\
\text { O: } 18\end{array}$ & $\begin{array}{c}\text { T: } 7 \% \\
\text { O: } 88 \%\end{array}$ & $\begin{array}{c}\text { T: } 4 \% \\
\text { O: } 44 \%\end{array}$ & $\begin{array}{c}\text { T: } 2 \% \\
\text { O: } 18 \%\end{array}$ \\
\hline
\end{tabular}

Source: Author after data for the Comunidad de Madrid [30,31].

How public procurement impinges on each food sector depends on the relative weight of the corresponding demand compared to total production. Honey, cereals, and meat illustrate that the positive impact of public food procurement would be relatively low. Even under a scenario of $100 \%$ local supply, it would account for a minor part of the total production. At the other extreme, we find potatoes and fruit, for which the expected demand outstrips the local supply capacity. The rest of the products lie between these two extremes. If all public food procurement is supplied locally, it would 
absorb around $10 \%$ of the production of meat, $20 \%$ of vegetables, oil, pulse, and nuts, and around $34 \%$ of milk.

If public procurement were to include both local and organic production as criteria, then that demand could not be met by farmers in the Comunidad de Madrid, except for honey and oil. This low local supply capacity is paramount in the case of fruit, potatoes, or pulse, and is a consequence of the reduced number of organic farmers and the limited surface allocated for certified organic production-i.e., 1 Ha for potatoes and 0.5 for pulse in the whole Comunidad de Madrid in 2019 [31]. These figures do not include agroecological projects without a third-party organic certification.

We compare these general figures with specific data obtained from the municipal kindergartens in the city of Madrid, where a transition program for canteens is underway, thereby improving the children's diets, and progressively incorporating organic foods onto the menu. Organic pulses stand out above the rest, as 32 out of 56 schools included them during the 2017-2018 academic year, and another 15 in the following year. Oil also has a significant presence, as 12 kindergarten used organic oil in 2017-2018 and another 10 in 2018-2019 [29]. Eggs, dairy, cereals, and-to a lesser extent-pasta, rice, vegetables, and fruits, have also been introduced to kindergartens. Therefore, other variables should be considered when designing policies for such a transition, to avoid impractical efforts due to food pricing or overly complex delivery. The current policy environment is shifting and in the quest for sustainable food systems, more ecological and relocalized food is increasingly rooted in the public agenda [5]. This case study focuses on one of the global zones best positioned to meet a higher percentage of food needs with local (considering a radio of $5000 \mathrm{~km}$ as local) crop production [34]. In this research, the production and consumption figures were restricted to the Comunidad de Madrid because it features the level of government that would work in both public procurement and agricultural policies. Given the demographic concentration in the metropolitan area of Madrid, food needs will continue to be met with a supply area that exceeds the administrative boundaries of the Comunidad de Madrid.

Local community, and (especially) farmer engagement, is needed to accelerate this transition [35], which will depend on their perceptions of the problem and their expectations and aspirations. Figure 4 outlines for which factors there is strong consensus between stakeholders who perceive them as constraints (closer to the y-axis), or as positive drivers fostering local farmers and their connection to local markets (closer to the $x$-axis). The other factors along the diagonal arouse as many negative as positive perceptions. This figure also illustrates when farmers had a different opinion from the rest of the stakeholders; in this sense, it is highly significant that public procurement stands out from the rest, challenging the idea of public food procurement as leverage for agricultural development and smallholder farmers' improved conditions. In the next section, we discuss these results in light of current debates and local contexts. 


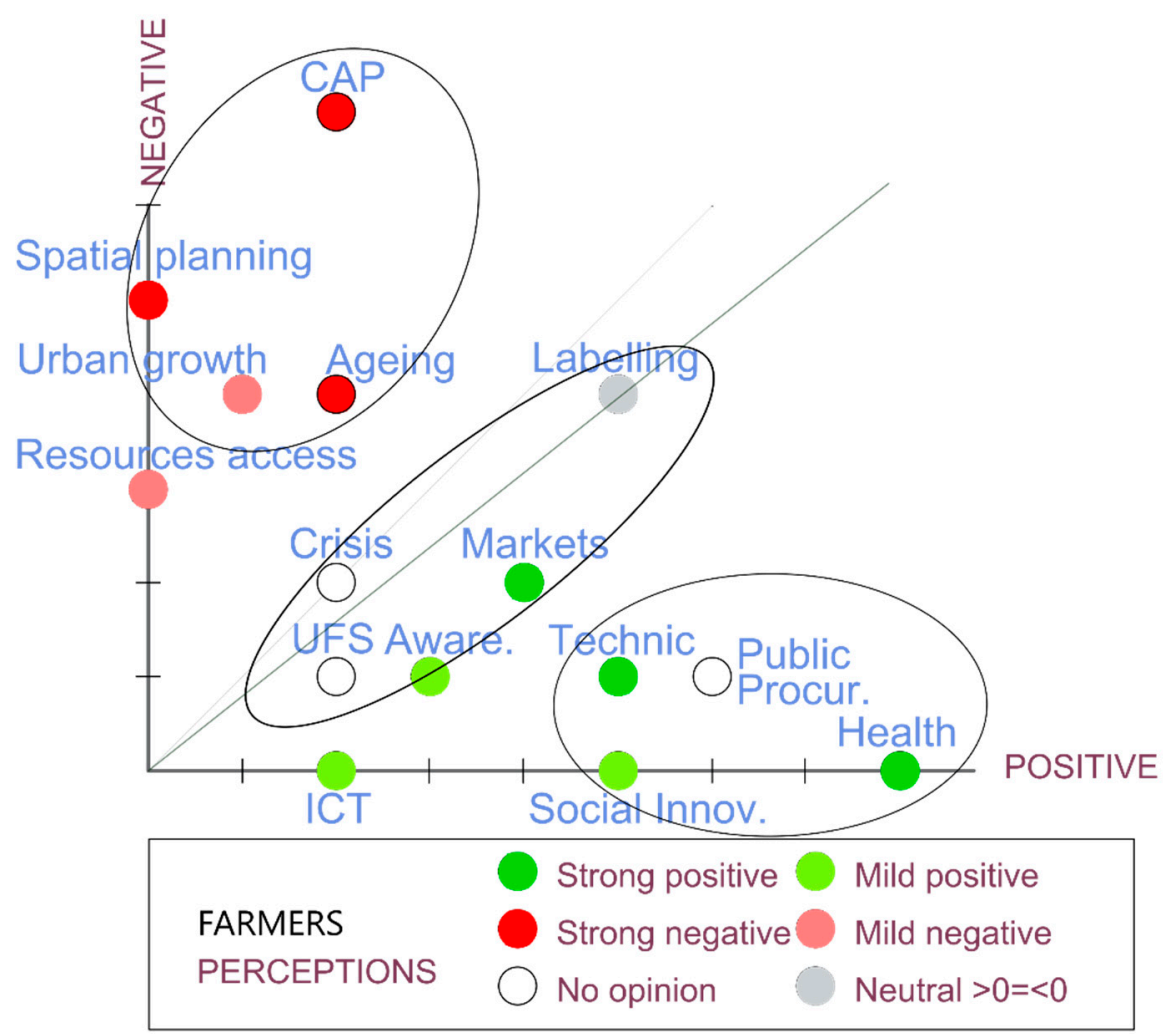

Figure 4. Perception of drivers and constrains, comparison between farmers and other stakeholders.

\section{Discussion}

\subsection{Struggling to Maintain Agriculture}

The importance of economics and income stability is highlighted when the entire productive sector in the area agrees with its peers in other parts of the globe, in its concern for economic viability. This factor takes precedence over other issues and makes other objectives invisible [36]. The year of 2020 started with large-scale farmer protests against the low prices they obtain while costs keep rising.

Rural agricultural abandonment and the peri-urban cessation of agrarian activities have common drivers related to farm stability and viability (low farm income, low dynamism, aging farmer populations, etc. [33], but some others are intrinsic to the peri-urban location and competition between uses, associated to urban attractiveness and pressure on the land [37]. Farmers and stakeholders were sensitive to their own locally evolving contexts, in which the construction sector has slowed down, and urban sprawl deceleration has reduced the pressure on peri-urban agricultural land. Farmers' relationships with the processes that transform agrarian land for urban uses are also often ambivalent.

In times of crisis, employment in agriculture is more stable, but in the case of Madrid, public policies give priority to the building sector, which is understood as offering a better chance for economic recovery and colliding with necessary land use protections and commitments to agriculture.

This research shows that in the region, conventional farmers tend to employ a "complaint-mode", whereas agroecological farmers (and some agrarian unions like Confederation of Associations of Farmers, Confederación de Organizaciones Agrarias y Ganaderas, COAG) are prone to innovation and exploring new options. In the academy, the concept of hybridization is paramount and applied above all else to commercialization and consumption, such that the supply system combines local and global, agro-ecological, ecological, and conventional production. Farmers considered themselves to lead this process. However, this process will work better if this leadership considers global forces, and how to intertwine their demands with those of social movements and local governments. 
The responses from alternative food networks (AFNs) were oriented toward reducing the number of intermediaries to seize control over prices [38]. These alternative networks are based on relationships of solidarity; such farmers do not seek to maximize their production and profits but instead respond to motivations that are less instrumental, for which economic aspects and income are not the priority [39]. Paradoxically, despite these AFNs' intentions to reduce intermediaries and dependencies through the establishment of direct and more egalitarian relationships between production and consumption, in practice, these relationships are very precarious and often give rise to notable levels of self-exploitation [40]. Food and agroecological movements are aware of this contradiction and stress the importance of changing other stakeholders' attitudes towards food and farmers, and providing real support. Indeed, consumer groups, social movements, and social researchers attach as much importance to the promotion of production as they do to awareness and education about consumption and food culture.

\subsection{Building Resilience and an Enabling Environment for Sustainable Food Systems}

Most agents recognized the general factors operating at a planetary scale, such as global competition and the corporate market power [41]. However, the agents offered no explicit references to other global challenges such as planning for resilience or disaster risk reduction (and, specifically, food security) in the context of climate change and protracted crisis [42,43]. Farmers, activists, technicians, and researchers linked to agroecology acknowledged that intensive agriculture erodes the basis for biodiversity "which threaten the provision of ecosystems services and the ultimate sustainability of agriculture" [23]. It is a matter of concern that this problem is not recognized by other people who occupy a position of responsibility in land management or the food sector. Even if they do not always name these issues as such, the agroecological farmers and social movement described themselves as being part of a transition towards improved socio-ecosystem resilience, for which there is no financial support.

Institutional (weak) attempts to promote local consumption have not had a substantial impact on the conditions of the horticultural farmers in the area. Public procurement has been claimed to be a powerful instrument to support local production [17], but to achieve that goal it needs to be carefully implemented, while acknowledging that its impact will be stronger if it integrates local, organic and social criteria. Although international references state that public procurement accounts for "on average 12 percent of gross domestic product and about 29 percent of total government spending" [44], food is not the lion's share. In the case of the Comunidad de Madrid, public food procurement accounted for $0.5 \%$ of the total GDP by 2018. Even so, public food procurement has great potential as a tool to boost job creation, innovation, environmental sustainability and social inclusion [45]. Its economic impact among local farmers varies considerably, and represents a moderate percentage of agricultural output: on average, it represents $10 \%$ of the food produced in the region (considering eggs, pulse, potatoes, oil, vegetable, fruit, nuts, honey, cereals, milk and dairy, and meat). If the public procurement demand were local and organic, only the demand for honey and oil could be met. For other food, there is currently not sufficient production. Right to food movements are also calling for a shift towards agroecological public procurement in food aid, both globally [46] and locally [47,48]. It reinforces the idea for joint action of farmers, agroecological and right to food movements as the transition in public procurement is narrowly intertwined with increasing the available agroecological production in the region. Despite its theoretical potential, the sector remains skeptical that such a strategy could easily work. The lack of enthusiasm for public procurement may emanate from the fact that it is a gradual process and difficult to operationalize. There are also organizational barriers to entry for the "standard" farmer, as the process is complex and a farmer's capacity to react is limited. Organic farmers mostly orient their production to the market, which has shown increasing demand for top quality food. The stakeholders most predisposed to taking on the challenge of supplying organic food are agroecological farmers, but they often lack a third-party certification, and, because of their relatively small size, they can face problems in complying with the requirements, and the volume of 
production. Indeed, the agroecological sector is preparing to respond to a potential increase in demand due to committed public procurement.

\section{Conclusions}

There is much literature praising peri-urban agriculture's virtues. However, in the surroundings of the Madrid metropolitan area, the continuity of agriculture is at risk. It faces structural problems and its relative weight decreases steadily. According to stakeholder perceptions, peri-urban farming around Madrid's metropolitan area is under threat as a direct consequence of the CAP and other public policies related to spatial planning and urban growth. The fact that land is protected in most of the area, as it belongs to a Regional Park, has not stopped extraction sites and buildings scattered across the riverside.

Interest in sustainable diets and health gains prominence between consumers, and all stakeholders agree that this represents a key opportunity to favor changes in the food system. So far, local reactions are not widespread but limited to farmers that are shifting to organic production and quality labels to fill a market niche for healthy and high quality food. Others orient their production toward local markets through short supply chains.

Stakeholders also highlight public policies related to raise awareness, and food procurement, as important drivers of change. Nevertheless, farmers do not agree on the former. In fact, public food procurement is the factor in which farmers' perceptions differ most from the rest of the stakeholders. Public policies should take into account the reasons behind this skepticism. Policies should address the difficulties that small and agroecological farmers face to be integrated into public food procurement programs. There are operational and organizational barriers to entry for the "standard" farmer, as the process is complex and a farmer's capacity to react is limited.

Given the weak presence of organic production in the region, public food procurement will fail to drive job creation, innovation, and environmental sustainability if it is not accompanied by measures addressing the productive sector. This process will not work immediately, so public procurement should be supplemented by public policies to promote the ecological transition and the entrance of new farmers, in those sub-sectors with more favorable conditions. Public food procurement represents a minor part of the food flow; nevertheless, it has the potential to become a relevant driver for transformation if public institutions, and specifically the local government, commit to playing an exemplary role. Farmers should have a leading role in the transition to sustainable food systems, and indeed, agroecological farmers are ready to be part of this process; thus, improving the resilience of the rural-urban system.

Author Contributions: Conceptualization, M.S.-R.; methodology, M.S.-R. and J.d.V.; field work, A.C.; investigation, M.S.-R., A.C. and J.d.V.; data curation, M.S.-R., and A.C.; writing-original draft preparation, M.S.-R.; writing-review and editing, M.S.-R. and J.F.T.; visualization, M.S.-R.; funding acquisition, J.F.T. All authors have read and agreed to the published version of the manuscript.

Funding: This research was funded by Instituto Nacional de Investigación y Tecnología Agraria y Alimentaria, grant number APCIN2016-00065-00-00.

Acknowledgments: We thank the municipality of Ciempozuelos for hosting the workshop of the Territory Game, Laura Jiménez and Raquel Clemente for conducting part of the phone survey and Cristina de Benito, Olga Moreno and Carolina Yacamán for facilitating it. We thank also the experience and knowledge shared by farmers, practitioners and activists from AUPA and Madrid Agroecologico, AGIM-COAG, UCAM, Comunidad de Regantes de la Real Acequia del Jarama, Heliconia, Surcos Urbanos, IMIDRA, CSIC, DG Agricultura y Ganadería CM and all the participants in workshops and respondents to the questionnaires.

Conflicts of Interest: The authors declare no conflict of interest.

\section{References}

1. Marsden, T.; Franklin, A. Replacing neoliberalism: Theoretical implications of the rise of local food movements. Local Environ. 2013, 18, 636-641. [CrossRef] 
2. Dubbeling, M.; Zeeuw, H.D.; Veenhuizen, R.V. Cities, Poverty and Food: Multi-Stakeholder Policy and Planning in Urban Agriculture; Practical Action Publishing: Rugby, UK, 2010; pp. 1-2.

3. FAO. The Role of Cities and Local Governments in Responding to the Emergency; Policy Briefing: Rome, Italy, 2020; p. 1.

4. Tilzey, M. Global Politics, Capitalism, Socio-Ecological Crisis, and Resistance: Exploring the Linkages and the Challenges. In Proceedings of the Colloquium Global Governance/Politics, Climate Justice \& Agrarian/Social Justice: Linkages and Challenges, Hague, The Netherlands, 4-5 February 2016; ICAS: Den Haag, The Netherlands, 2016.

5. A Farm to Fork Strategy for a Fair, Healthy and Environmentally-Friendly Food System. Available online: https://ec.europa.eu/food/farm2fork_en (accessed on 6 July 2020).

6. Altieri, M.; Hecht, S.; Liebman, M.; Magdoff, R.; Norgaard, R.; Sikor, T. Agroecología: Bases Científicas Para una Agricultura Sustentable; Centro de Investigación, Educación y Desarrollo: Lima, Peru, 1997; p. 9.

7. Francis, C.; Lieblein, G.; Gliessman, S.; Breland, T.A.; Creamer, N.; Harwood, R.; Salomonsson, L.; Helenius, J.; Rickerl, D.; Salvador, R. Agroecology: The ecology of food systems. J. Sustain. Agric. 2003, 22, 99-118. [CrossRef]

8. Gliessman, S. Transforming Food Systems with Agroecology. Agroecol. Sustain. Food Syst. 2016, 40, 187-189. [CrossRef]

9. Nicholls, C.I.; Altieri, M.A.; Vazquez, L. Agroecology: Principles for the conversion and redesign of farming systems. J. Ecosyst. Ecography S 2016, 5, 2-8. [CrossRef]

10. Holt-Giménez, E. Food security, food justice, or food sovereignty. In Cultivating Food Justice: Race, Class, and Sustainability; The MIT Press: Cambridge, MA, USA, 2011; pp. 309-330.

11. Theories and Models of the Peri-Urban Interface: A Changing Conceptual Landscape. Available online: http://citeseerx.ist.psu.edu/viewdoc/download?doi=10.1.1.195.3108\&rep=rep1\&type=pdf (accessed on 14 July 2020).

12. Ávila-Sánchez, H. Socio-territorial changes in peri-urban food production spaces in Central Mexico. Norois Environ. Aménagement Société 2011, 221, 39-51. [CrossRef]

13. Lohrberg, F.; Lička, L.; Scazzosi, L.; Timpe, A. It is a business! Business models in urban agriculture. In Urban Agriculture Europe; Jovis: Berlin, Germany, 2016; pp. 82-91.

14. Lohrberg, F.; Lička, L.; Scazzosi, L.; Timpe, A. From urban food gardening to urban farming. In Urban Agriculture Europe; Jovis: Berlin, Germany, 2016; pp. 22-28.

15. Food \& Beverage Retail España. 2018. Available online: https://www.cushmanwakefield.com/es-es/spain/ins ights/food-beverage-retail-espana-2018 (accessed on 25 January 2020).

16. Ilieva, R.T. Urban food systems strategies: A promising tool for implementing the SDGs in practice. Sustainability 2017, 9, 1707. [CrossRef]

17. Soldi, R. Sustainable Public Procurement of Food; European Union: Brussels, Belgium, 2018; pp. $27-32$.

18. Sonnino, R. Quality food, public procurement, and sustainable development: The school meal revolution in Rome. Environ. Plan. A 2009, 41, 425-440. [CrossRef]

19. Caldeira, S.; genannt Bonsmann, S.S.; Bakogianni, I.; Gauci, C.; Calleja, A.; Furtado, A. Public Procurement of Food for Health; Publications Office of the EU: Luxembourg, 2017; pp. 10-11.

20. Debolini, M.; Marraccini, E.; Dubeuf, J.P.; Geijzendorffer, I.R.; Guerra, C.; Simon, M.; Targetti, S.; Napoléone, C. Land and farming system dynamics and their drivers in the Mediterranean Basin. Land Use Policy 2018, 75, 702-710. [CrossRef]

21. Wiskerke, J.S. On places lost and places regained: Reflections on the alternative food geography and sustainable regional development. Int. Plan. Stud. 2009, 14, 369-387. [CrossRef]

22. Béné, C.; Prager, S.D.; Achicanoy, H.; Alvarez Toro, P.; Lamotte, L.; Bonilla Cedrez, C.; Mapes, B.R. Understanding food systems drivers: A critical review of the literature. Glob. Food Secur. 2019, 149-159. [CrossRef]

23. Terres, J.M.; Scacchiafichi, L.N.; Wania, A.; Ambar, M.; Anguiano, E.; Buckwell, A.; Coppola, A.; Gocht, A.; Källström, H.N.; Pointereau, P. Farmland abandonment in Europe: Identification of drivers and indicators, and development of a composite indicator of risk. Land Use Policy 2015, 49, 20-34. [CrossRef]

24. Sassen, S. Global Networks, Linked Cities; Psychology Press: Oxford, UK, 2002; pp. 124-126.

25. Programa de Desarrollo Rural de la Comunidad de Madrid 2014-2020. Available online: https://www.comu nidad.madrid/sites/default/files/doc/medio-ambiente/cma_agr_anexo_dafo.pdf (accessed on 20 May 2020). 
26. Estructura de la Industria Alimentaria y las Tendencias del Consumo en la Comunidad de Madrid: Base Para la Realización de Estudios Sectoriales. Available online: https://www.comunidad.madrid/publicacion/ref/9377 (accessed on 3 May 2020).

27. Estrategia de Alimentación Saludable y Sostenible, 2018-2020. Available online: https://transparencia. madrid.es/portales/transparencia/es/Organizacion/Planes-y-memorias/Planes/Estrategia-de-AlimentacionSaludable-y-Sostenible-del-Ayuntamiento-de-Madrid-para-el-periodo-2018-2020/?vgnextfmt=default\&vgnex toid=9a270d9894665610VgnVCM1000001d4a900aRCRD\&vgnextchannel=d869508929a56510VgnVCM100000 8a4a900aRCRD (accessed on 29 May 2020).

28. Spanish Urban Agenda. Available online: https://www.aue.gob.es/en/the-spanish-urban-agenda (accessed on 10 May 2020).

29. Lardon, S.; Piveteau, V. Méthodologie de diagnostic pour le projet de territoire: Une approche par les modèles spatiaux. Géocarrefour 2005, 80, 75-90. [CrossRef]

30. La alimentación en la Comunidad de Madrid. Available online: http://www.madrid.org/cs/Satellite?blobco l=urldata\&blobheader=application \%2Fpdf\&blobheadername1=Content-Disposition\&blobheadervalue1= filename\%3DLa+alimentaci\%C3\%B3n+en+la+Comunidad+de+Madrid.pdf\&blobkey=id\&blobtable=Mu ngoBlobs\&blobwhere=1352883644096\&ssbinary=true (accessed on 22 June 2018).

31. Superficies y Producciones Anuales de Cultivos. Available online: https://diario.madrid.es/madridalimenta/ wp-content/uploads/sites/36/2018/07/EstrategiaAlimentacion-SS-2018-2020.pdf (accessed on 15 August 2020).

32. Memoria 2018 de la Estrategia de Alimentación Saludable y Sostenible. Available online: https://diario. madrid.es/madridalimenta/wp-content/uploads/sites/36/2019/06/MEMORIA_EJECUCION_2019_ESTRATE GIA_ALIMENTACION.pdf (accessed on 1 October 2019).

33. Simon-Rojo, M.; Couceiro-Arroyo, A.; Fariña-Tojo, J. La relocalización alimentaria débil: Desconexión entre agentes del territorio y planificación espacial/Weak food relocation: Disconnection between territorial agents and spatial planning. Urbano 2019, 106-123.

34. Kinnunen, P.; Guillaume, J.H.; Taka, M.; D’Odorico, P.; Siebert, S.; Puma, M.J.; Jalava, M.; Kummu, M. Local food crop production can fulfil demand for less than one-third of the population. Nat. Food 2020, 1, $229-237$. [CrossRef]

35. Gliessman, S. Breaking away from Industrial Food and Farming Systems: Seven Case Studies of Agroecological Transition; International Panel of Experts on Sustainable Food Systems (IPES-Food): Brussels, Belgium, 2018; pp. 94-95.

36. Landis, D.A. Designing agricultural landscapes for biodiversity-based ecosystem services. Basic Appl. Ecol. 2017, 18, 1-12. [CrossRef]

37. Opitz, I.; Berges, R.; Piorr, A.; Krikser, T. Contributing to food security in urban areas: Differences between urban agriculture and peri-urban agriculture in the Global North. Agric. Hum. Values 2016, 33, 341-358. [CrossRef]

38. Wezel, A.; Fleury, P.; David, C.; Mundler, P. The food system approach in agroecology supported by natural and social sciences. In Agroecology, Ecosystems and Sustainability; CRC Press/Taylor and Francis Group: Boca Raton, FL, USA, 2014; pp. 181-199.

39. Galt, R.E. Placing food systems in first world political ecology: A review and research agenda. Geogr. Compass 2013, 7, 637-658. [CrossRef]

40. Hinrichs, C.C. Embeddedness and local food systems: Notes on two types of direct agricultural market. J. Rural Stud. 2000, 16, 295-303. [CrossRef]

41. Ross, N.J. How civic is it? Success stories in locally focused agriculture in Maine. Renew. Agric. Food Syst. 2006, 114-123. [CrossRef]

42. Maye, D. 'Smart food city': Conceptual relations between smart city planning, urban food systems and innovation theory. City Cult. Soc. 2019, 16, 18-24. [CrossRef]

43. City Regions as Landscapes for People Food and Nature. Available online: https://www.un.org/esa/ffd/wpcontent/uploads/sites/2/2015/10/CityRegions_AsLandscapesforPeopleFoodandNature_smallest.pdf (accessed on 10 October 2019).

44. World Bank. Benchmarking Public Procurement 2015: Pilot Report Assessing Public Procurement Systems in 10 Economies; World Bank: Washington, DC, USA, 2015; p. 2.

45. Hajnalka, P.; Gomez, M.; Franchi, V. Strengthening Sector Policies for Better Food Security and Nutrition Results. Public Food Procurement; FAO: Rome, Italy, 2017; p. 10. 
46. Report Presented at the 16th Session of the United Nations Human Rights Council [A/HRC/16/49]. Available online: http://www.srfood.org/images/stories/pdf/officialreports/20140310_finalreport_en.pdf (accessed on 1 October 2019).

47. Álvarez Vispo, I.; López, D. Hacia un sistema alimentario sostenible en el Estado Español. AE. Rev. Agroecol. Divulg. 2018, 34, 18-21.

48. Hambre e Inseguridad Alimentaria en la Comunidad de Madrid. Available online: https://oda-madrid.org /wp-content/uploads/2020/05/InsseguridadAlimentaria_CMadrid2020.pdf (accessed on 13 July 2020).

(C) 2020 by the authors. Licensee MDPI, Basel, Switzerland. This article is an open access article distributed under the terms and conditions of the Creative Commons Attribution (CC BY) license (http://creativecommons.org/licenses/by/4.0/). 